\title{
Appendix
}

Schedule of leases attached to a plan of the Ormond Street area, BL Crace XV, 27

This is a transcription of the schedules of leases attached to figure 10 . The schedules cover the period 1702-20 and appear to be originals, unlike the plan of 1752, and are in two different hands. The schedules are evidence of the wide range of people taking building leases, including the builders Ragdall, Hawkins and Betts, gentry such as Sir John Smith and Thomas Wentworth Esq. and one woman, Elizabeth London. There is also a division between those such as London who inhabited the houses they financed and those instances where the property has been let to tenants. The right-hand schedule also shows the considerable time taken to build this development, which was still underway at the time the schedule was drawn up as the later peppercorn rents indicate.

NB Spellings and layout given as in the original, although ' $S$ ' has been substituted for 'long s'.

$-=$ illegible word

do $=$ ditto

Mid = Midsummer

Mich $=$ Michaelmas

\section{Cartouche inscription}

At Xmas 1686. A Lease of the Under Menshon ${ }^{\mathrm{d}}$ Ground was granted to $\mathrm{D}^{\mathrm{r}} \mathrm{Nich}^{\mathrm{s}}$ Barbon, by the ffeofees of Rugby School for 50 Yrs at $50 £$ ann. and sometime after the $\mathrm{D}^{\mathrm{r}}$ assignes $\mathrm{y}$. ${ }^{\mathrm{e}}$ same to $\mathrm{S}^{\mathrm{r}} \mathrm{W}^{\mathrm{m}}$ Milman $\mathrm{K}^{\mathrm{t}}$ and in 1702 by a decree in Chancery $y^{\mathrm{e}} \mathrm{s}^{\mathrm{d}}$ ffeofees did Grant to $\mathrm{S}^{\mathrm{r}} \mathrm{W}^{\mathrm{m}}$ A farther term of $43 \mathrm{Y}^{\mathrm{rs}}$ from the Expira ${ }^{\mathrm{n}}$ of $\mathrm{y}^{\mathrm{e}}$ beforemenshon ${ }^{\mathrm{d}}$ lease at $60 \mathfrak{E}$ ann whic S. ${ }^{\mathrm{d}}$ lease will expire at Xmass 1779.

\section{Left-hand schedule}

An Inventory or Schedule of all the Building Leases Given by $\mathrm{S}^{\mathrm{r}} \mathrm{W}^{\mathrm{m}}$ Milman Kt dece ${ }^{\mathrm{d}}$. of the several houses in and $\mathrm{Ab}^{\mathrm{t}}$ Great Ormond Street, Including $\mathrm{y}^{\mathrm{e}}$ West side of the Lower End of Red Lyon Street \& Conduit Street $\mathrm{w}^{\text {th }}$ the Dates of the Leases, to whome Given, Time of Commencem. Dates of Leases \& Tenants in possesion. Anna ${ }^{1}$. Rents. 


\begin{tabular}{|c|c|c|c|c|c|c|}
\hline Dates of Leases & $\begin{array}{l}\text { To Whom Given and time of } \\
\text { Commencmt and term }\end{array}$ & $\begin{array}{l}\text { Tenants in } \\
\text { possession }\end{array}$ & $\begin{array}{l}\text { Annu } \\
\text { rents }\end{array}$ & & & ime of Expiration \\
\hline & & & $£$ & $s$ & $d$ & \\
\hline 1702 Feb 18 & $\begin{array}{l}\text { Lease to Jos Walker for } 61 \text { years } \\
\text { from Ladyday } 1703\end{array}$ & Walker & 4 & 0 & 0 & Ladyday 1764 \\
\hline do & $\begin{array}{l}\text { To } \operatorname{Sim}^{\mathrm{n}} \text { Betts for } 61 \text { years from } \\
\text { Ladyday } 1703\end{array}$ & Degley & 4 & 0 & 0 & do \\
\hline do & $\begin{array}{l}\text { To W Ragdall Lamp Office for } \\
61 \text { yrs from Ladyday } 1703\end{array}$ & Johnson & 3 & 0 & 0 & do \\
\hline do & do & Major Aldee & 4 & 8 & 0 & do \\
\hline do & $\begin{array}{l}\text { To John Ragdall } 61 \text { years from } \\
\text { Ladyday } 1703\end{array}$ & Ragdall & 3 & 10 & 0 & do \\
\hline 26 & $\begin{array}{l}\text { To } \mathrm{W}^{\mathrm{m}} \text { Hawkins for } 61 \text { yrs from } \\
\text { Xmas before }\end{array}$ & do & 5 & 0 & 0 & Xmas 1763 \\
\hline do & do & Palmer & 6 & 0 & 0 & do \\
\hline do & $\begin{array}{l}\text { To David Fifield for } 60 \text { yrs from } \\
\text { Ladyday } 1703\end{array}$ & Harcourt & 8 & 0 & 0 & Ladyday 1763 \\
\hline Mar 5 & $\begin{array}{l}\text { To J }- \text { - Bedford for } 60 \mathrm{yrs} \\
\text { from Ladyday } 1703\end{array}$ & Child & 6 & 0 & 0 & do \\
\hline do & $\begin{array}{l}\text { To Paul Gainsford for } 60 \text { yrs } \\
\text { from Ladyday } 1703\end{array}$ & Crew & 6 & 0 & 0 & do \\
\hline do & $\begin{array}{l}\text { To - Sparks for } 60 \text { yrs from } \\
\text { Ladyday } 1703\end{array}$ & Fifield & 6 & 0 & 0 & do \\
\hline 1703 Ap6 & $\begin{array}{l}\text { To Edw }{ }^{\mathrm{d}} \text { Buckingham for } 61 \mathrm{yrs} \\
\text { from Mids } 1704\end{array}$ & Holl & 8 & 0 & 0 & Mid 1765 \\
\hline Sep 25 & $\begin{array}{l}\text { To Jon }^{\mathrm{n}} \text { Kent for } 61 \text { yrs from } \\
\text { Ladyday } 1704\end{array}$ & Bush & 8 & 0 & 0 & Mid 1765 \\
\hline 26 & $\begin{array}{l}\text { To }-- \text { Sparks for } 61 \text { yrs from } \\
\text { Ladyday } 1704\end{array}$ & - & 8 & 0 & 0 & do \\
\hline do & $\begin{array}{l}\text { To } \mathrm{W}^{\mathrm{m}} \text { Hawkins for } 61 \text { yrs from } \\
\text { Xmas before [sic] }\end{array}$ & Dennis jn & 4 & 0 & 0 & Xmas 1763 \\
\hline do & $\begin{array}{l}\text { To W Ragdall for } 61 \text { yrs } \\
\text { from Ladyday } 1704\end{array}$ & Dickenson & 4 & 12 & 0 & Ladyday 1765 \\
\hline do & $\begin{array}{l}\text { To }-- \text { for } 61 \text { yrs from Xmas } \\
--\end{array}$ & Latham & 4 & 0 & 0 & Xmas 1764 \\
\hline 1705 Ap3 & $\begin{array}{l}\text { To David Fifield for } 58 \text { yrs from } \\
\text { Ladyday } 1705\end{array}$ & Fifield & 6 & 0 & 0 & Ladyday 1763 \\
\hline do & $\begin{array}{l}\text { To James Paget for } 58 \text { yrs from } \\
\text { Ladyday } 1705\end{array}$ & Pagett & 6 & 0 & 0 & do \\
\hline July 2 & $\begin{array}{l}\text { To } \mathrm{W}^{\mathrm{m}} \text { Dagell [Dagett?] for } 50 \\
\text { yrs from Midd } 1705\end{array}$ & Millington & 8 & 0 & 0 & Xmas 1764 \\
\hline Nov 5 & $\begin{array}{l}\text { To } \mathrm{R}^{\mathrm{d}} \text { Stokes for } 61 \mathrm{yrs} \\
\text { from Xmas } 1705\end{array}$ & Lucas & 4 & 0 & 0 & Xmas 1766 \\
\hline do & To do for $60 \mathrm{yrs}$ & do & 4 & 0 & 0 & Mich ms 1765 \\
\hline do & $\begin{array}{l}\text { To - Sparks for } 61 \text { yrs } \\
\text { from Michs before }\end{array}$ & Stevens & 4 & 0 & 0 & Mich 1766 \\
\hline Feb 20 & $\begin{array}{l}\text { To Sim }{ }^{\mathrm{n}} \text { Betts for } 61 \text { yrs } \\
\text { from Xmas } 1705\end{array}$ & Ingram & 4 & 0 & 0 & Xmas 1766 \\
\hline 26 & $\begin{array}{l}\text { To Matt Allam for } 61 \mathrm{yrs} \\
\text { from Ladyday } 1706\end{array}$ & Bedford & 4 & 0 & 0 & Ladyday 1766 \\
\hline do & To do from do for do & do & 4 & 0 & 0 & do \\
\hline 1706 Ap20 & $\begin{array}{l}\text { To Thos Wentworth Esq } \\
\text { for } 58 \text { yrs from Ladyday } \\
1706\end{array}$ & Wentworth & 8 & 0 & 0 & Ladyday 1764 \\
\hline
\end{tabular}




\begin{tabular}{|c|c|c|c|c|c|c|c|}
\hline \multirow{2}{*}{\multicolumn{2}{|c|}{ Dates of Leases }} & \multirow{2}{*}{$\begin{array}{l}\text { To Whom Given and time of } \\
\text { Commencmt and term }\end{array}$} & \multirow{2}{*}{$\begin{array}{l}\text { Tenants in } \\
\text { possession }\end{array}$} & \multicolumn{3}{|c|}{ Annual rents } & \multirow{2}{*}{$\begin{array}{l}\text { Time of } \\
\text { Expiration }\end{array}$} \\
\hline & & & & $E$ & $s$ & $d$ & \\
\hline \multicolumn{2}{|c|}{ May 8} & To do for stables for do & do & 2 & 0 & 0 & Ladyday 1764 \\
\hline \multicolumn{2}{|r|}{5} & $\begin{array}{l}\text { To Jon Kent for } 61 \text { yrs } \\
\text { from Midd } 1706\end{array}$ & $\mathrm{Md}^{\mathrm{m}}$ Finch & 7 & 17 & 6 & Mid 1767 \\
\hline \multicolumn{2}{|r|}{ do } & $\begin{array}{l}\text { To Jon Ragdall for } 61 \text { yrs } \\
\text { from Midd } 1706\end{array}$ & Dagley & 7 & 17 & 6 & do \\
\hline \multicolumn{2}{|r|}{ do } & $\begin{array}{l}\text { To } \operatorname{Sim}^{\mathrm{n}} \text { Betts for } 61 \mathrm{yrs} \\
\text { from Midd } 1706\end{array}$ & $\mathrm{Md}^{\mathrm{m}}$ Pearse & 7 & 14 & 0 & Mid 1767 \\
\hline \multicolumn{2}{|r|}{2} & $\begin{array}{l}\text { To Jos Walker for } 61 \text { yrs } \\
\text { from Midd } 1706\end{array}$ & Chisledon & 7 & 9 & 6 & do \\
\hline \multicolumn{2}{|c|}{1710 Mar 12} & $\begin{array}{l}\text { To } \mathrm{M}^{\mathrm{r}} \text { Barlow for } 61 \text { yrs } \\
\text { from Ladyday before }\end{array}$ & Barlow & 5 & 0 & 0 & Ladyday 1770 \\
\hline \multicolumn{2}{|r|}{ do } & To do for do from do & Yate & 4 & 0 & 0 & do \\
\hline \multicolumn{2}{|r|}{ do } & To do for do from do & Yate & 1 & - & 6 & do \\
\hline \multicolumn{2}{|c|}{1710 May 29} & $\begin{array}{l}\text { To Edw }{ }^{\mathrm{d}} \text { Chapman for } 61 \\
\text { yrs from Ladyday before }\end{array}$ & Eales & 14 & 0 & 0 & Ladyday 1771 \\
\hline \multicolumn{2}{|c|}{1711 May 1} & $\begin{array}{l}\mathrm{M}^{\mathrm{r}} \text { Brownjohn for } 61 \mathrm{yrs} \\
\text { from Mid } 1711\end{array}$ & Brownjohn & 10 & 0 & 0 & Mid 1772 \\
\hline \multicolumn{2}{|c|}{1710 July 20} & $\begin{array}{l}\text { to Edw Chapman for } 50 \text { yrs from } \\
\text { Mid } 1716\end{array}$ & Eales & 12 & 10 & 0 & Mid 1775 \\
\hline \multirow[t]{2}{*}{1717} & Apr 10 & $\begin{array}{l}\text { to Dennis Sen for } 54 \text { yrs } \\
\text { from Ladyday before }\end{array}$ & Dennis & 3 & 0 & 0 & Ladyday 1771 \\
\hline & & & Total & \multicolumn{3}{|c|}{ 228: 1400} & \\
\hline
\end{tabular}

\section{Right-hand schedule}

An Inventory or Schedule of all the Building leases which Wee the Heirs of the late $\mathrm{S}^{\mathrm{r}} \mathrm{W}^{\mathrm{m}}$ Milman dec ${ }^{\mathrm{d}}$. according to his articles $\mathrm{w}^{\text {th }} \mathrm{Jo}^{\mathrm{n}}$ Richbell $\mathrm{Jo}^{\mathrm{n}}$ Ragdall \& Edw ${ }^{\mathrm{d}}$ Chapman builders of a piece of ground part of Lambs Conduit Fields, lying on the East side of Red Lyon \& Conduit Street, for 61 yrs from Ladyday 1717 at $180 £$ p.ann: subjt to Taxes

\begin{tabular}{|c|c|c|c|c|c|c|}
\hline \multirow{3}{*}{$\begin{array}{l}\text { Dates of Leases } \\
\\
1719 \text { May } 16\end{array}$} & \multirow{3}{*}{$\begin{array}{l}\text { To Whom Given and time of } \\
\text { Commencmt and term } \\
\text { To Tho Mead for } 61 \\
\text { days from Ladyday } 1717\end{array}$} & \multirow{3}{*}{$\begin{array}{l}\text { Tenants in } \\
\text { possession }\end{array}$} & \multicolumn{4}{|c|}{$\begin{array}{l}\text { Annual rents } \text { Time of } \\
\text { Expiration }\end{array}$} \\
\hline & & & $£$ & $s$ & $d$ & \\
\hline & & & 7 & 0 & 0 & Ladyday 1778 \\
\hline do & To Edw ${ }^{d}$ Symson do do & Sympson & 7 & 7 & 0 & do \\
\hline do & To Eliz London do do & London & 6 & 0 & 0 & do \\
\hline May 29 & To Will $^{\mathrm{m}}$ Pain do do & Pain & 5 & 0 & 0 & do \\
\hline do & To do & do & 5 & 0 & 0 & do \\
\hline Aug 5 & To - Nurse do & Nurse & 6 & 0 & 0 & do \\
\hline Sep 22 & To Jo ${ }^{\mathrm{n}}$ Ragdall do & Martin & 6 & 0 & 0 & do \\
\hline do & do & do & 6 & 0 & 0 & do \\
\hline do & do & Mills & 5 & 0 & 0 & do \\
\hline do & To Jon Richball do & Reevs & 6 & 0 & 0 & do \\
\hline do & do & Frower & 7 & 0 & 0 & do \\
\hline do & do & Dry & 7 & 0 & 0 & do \\
\hline Jan 14 & To Brown \& Grey do & $\mathrm{M}^{\mathrm{r}}$ Smith & 7 & 7 & 0 & do \\
\hline 1720 Sep 27 & To $S^{r}$ John Smith do & $\mathrm{S}^{\mathrm{r}} \mathrm{Jo}^{\mathrm{n}}$ & 7 & 0 & 0 & do \\
\hline & & Smith & & & & \\
\hline Oct 21 & To Jon Ragdall do & Ragdall & 5 & 0 & 0 & do \\
\hline
\end{tabular}




\begin{tabular}{|c|c|c|c|c|c|c|}
\hline \multirow[t]{3}{*}{ Dates of Leases } & \multicolumn{2}{|c|}{ To Whom Given and time of Tenants in } & \multirow{2}{*}{\multicolumn{4}{|c|}{ Annual rents Time of Expiration }} \\
\hline & \multirow[t]{2}{*}{ Commencmt and term } & \multirow[t]{2}{*}{ possession } & & & & \\
\hline & & & $£$ & $s$ & $d$ & \\
\hline do & do & do & 5 & 0 & 4 & do \\
\hline do & To Walker \& Hiron do & Walker \& Hiron & 5 & 18 & 0 & do \\
\hline do & To Math Allum do & Allam & 5 & 0 & 0 & do \\
\hline do & ToJo $^{\text {n }}$ Gifford do & Gifford & 5 & 0 & 0 & do \\
\hline do & To Edw ${ }^{\mathrm{d}}$ Symson do & Symson & 5 & 0 & 0 & do \\
\hline do & To Jo ${ }^{\mathrm{n}}$ Cooper & Cooper & 8 & 8 & 0 & do \\
\hline 1720 Oct 21 & To Edw ${ }^{\mathrm{d}}$ Chapman do & Chapman & 7 & 7 & 0 & do \\
\hline do & do & do & 7 & 14 & 0 & do \\
\hline do & do & do & 6 & 0 & 0 & do \\
\hline do & do & do & 5 & 0 & 0 & do \\
\hline do & do & do & 5 & 0 & 0 & do \\
\hline do & do & do & 8 & 8 & 0 & do \\
\hline \multirow[t]{23}{*}{ do } & do & do & 5 & 16 & 8 & do \\
\hline & To Jon Ragdall & Pepper Corn & & & & do \\
\hline & do & & & & & do \\
\hline & do & & & & & do \\
\hline & do & & & & & do \\
\hline & do & & & & & do \\
\hline & do & & & & & do \\
\hline & do & & & & & do \\
\hline & do & & & & & do \\
\hline & To Jon Richbell & Pepper Corn & & & & do \\
\hline & do & & & & & do \\
\hline & do & & & & & do \\
\hline & do & & & & & do \\
\hline & do & & & & & do \\
\hline & do & & & & & do \\
\hline & To Edw ${ }^{\mathrm{d}}$ Chapman & Pepper Corn & & & & do \\
\hline & do & & & & & do \\
\hline & do & & & & & do \\
\hline & do & & & & & do \\
\hline & do & & & & & do \\
\hline & & & $£ 18$ & 0: 00 & & \\
\hline & & Brought Over & $228:$ & 14: & & \\
\hline & & Total Ground Rents & 408: & 14: & & \\
\hline
\end{tabular}

